\title{
INFLUENCE OF INTERNET DEPENDENCY ON YOUTH SELF-ACTUALIZATION
}

https://doi.org/10.37096/SHDISJ-19-1.1-0001

Golovanova Tetyana,

https://orcid.org/0000-0002-1461-5060

Vlasova Olena

https://orcid.org/0000-0002-9894-0038

\begin{abstract}
The purpose of the article is to analyze the influence of the Internet dependence of teenagers on the peculiarities of their self-actualization and to check the effectiveness of the developed program for increasing the self-actualization of such persons. The study involved 223 individuals. The following research methods were used in the work: testing (Kimberly Young Test, CAT Test and Situational Selfactualization Test), questionnaires, observations; statistical methods for carrying out qualitative and quantitative analysis of the research results (Student's criterion and Pearson criterion). Based on the data obtained, we have developed a program of psychological support for the self-actualization of youths by developing its competence in using Internet resources. The article shows that different uses of virtual space by young people affect their self-actualization in different ways; the social and psychological factors of increasing the virtual space utilization of young people have been found out. In the course of an empirical study carried out, the authors prove the statistically significant relationship that exists between the excessive capture of the personality of the youth by virtual space and its self-actualization. The analysis of the influence of various variants of use by young men of the virtual space (games, communication, information seeking) revealed a significant difference in the priority of the gaming activity of youth as a factor in the formation of Internet dependency and low self-actualization of the individual (the latter is understood by the authors as an integral individual indicator of personal growth of a person).
\end{abstract}

Keywords: Internet addiction, self-actualization, adolescence, virtual space.

\section{Introduction}

Self-actualization becomes an integrative factor, which involves solving the problems of human self-determination of a person, choosing its living environments, most adequate for selfrealization and the formation of life strategies. Information space as an active "living environment" of a person complements its existence, initiates new forms of manifestation of self-organization of man and creates new spheres of self-expression of personality. An analysis of the works shows that the formation of selfactualization of the person at the stage of adolescence is in harmony with the main neoplasms of this period of life, and therefore of great importance.

The concept of self-actualization is inextricably linked with the self-realization of the individual. The theoretical foundations of the problem of self-actualization of the individual are highlighted in the studies of many psychologists. Representatives of various psychological schools (psychoanalysis, neofreydism, humanistic and existential-humanistic conception, domestic theories and polysystem theory of selfactualization) were engaged in the analysis of selfactualization and self-actualization of the personality. In the study, we rely on the idea of representatives of the humanistic psychology of self-actualization as one of the highest human needs (A. Maslow, C. Rogers, C. Goldstein, V. Frankl et al.)., The position of the anthropological approach of domestic scientists (G. Batishchev, V. Andrushchenko, K. Goldstein, B. Gershunsky, L. Kogan, O. Losev and others); an activity approach that explains the mechanism of self-realization of a person (S. Rubinstein, O. Leontiev, L. Vygotsky, in Romenets and others). The pedagogical aspects of self-actualization as an active cognitive and creative activity are disclosed in the writings of $\mathrm{V}$. Boyko, V. Andreev, L. Kogan, I. Ivanov, L. Levchenko, M. Lazarev, V. Lozova, L. Sokhan, V. Mulyr, and others. Interest in our research is also represented by works that deal with selfactualization with self-knowledge (Y. Orlov) and self-development (N. Bityanova, O. Kyselyova, L. Kogan, S. Marynchak).

Investigators of the virtual space and the peculiarities of human interaction with it were investigated by NV Vodyanov, Yu. M. Lotman, V. Gudimov, K. Yang, A.E.Voyuskunsky, A.Kalmykov, E.S. Polat. The psychological problems of Internet addiction, the development and use of computer games are most thoroughly 
investigated in the works of authors such as $\mathrm{Yu} . \mathrm{V}$. Fomichova, AG Shmelev, SA Shapkin, IV Burlakov, K. Young, S.A. Klymenko, E.E. Lysenko, O.K. Tikhomirov, ON Arestova, Yu.D. Babaeva, D. Grossman, Lord Lord, and Roe.

The purpose of the article is to analyze the influence of the Internet dependence of teenagers on the peculiarities of their self-actualization and to check the effectiveness of the developed program for increasing the self-actualization of such persons.

In recent years, the research interest in the problem of self-actualization of a person has sharply increased. Increasing attention to this problem is due to the understanding of its decisive role in the development of personality (Maslow, 1999; Rogers, 1994).

Modern society needs a competent personality, able to take an active part in the development of science, culture, economics and social life. On the other hand, as the study of K. Riff and others, shows, happiness or subjective well-being of a person essentially depends on his ability to worry about other people, personal autonomy and vital competence, self-acceptance, the existence of life goals and the sense of personal growth (Vashchenko et al., 2016: 116-127). That is why the priority among the priorities of the parental socialization of the younger generation is the task of creating favorable conditions for the identification and development of abilities, satisfaction of interests and needs, the development of educational and cognitive activity and creative autonomy, and as a result - obtaining a higher level of self-actualization of youth in all spheres of life.

The working concept of self-actualization is considered by the authors in the understanding of humanistic psychology, according to which the condition of personal development of man is the presence of her leading motive, defined as selfactualization. It is defined as the desire of the bearer of the psyche to realize their personal potentials in all possible ways.

Theoretical analysis gives grounds to assert that the value-semantic component of selfactualization of persons of youth is characterized by a combination of such significant values as love, knowledge of the world, human nature, social activity for achieving positive changes in society. They are also guided by the motives of knowing themselves and the outside world (cognitive abilities) and social motives (communication). Self-actualization of personality can be characterized by the adequacy of its perception of reality; acceptance of oneself and others as they are; spontaneity of manifestations, simplicity and naturalness; the formation of internal moral norms; business orientation, ability to deal with oneself and their life tasks; autonomy and independence from the environment; the activity of one's own position in relation to reality; the immediacy of its estimates; lack of manifestations of hostility in interpersonal relations; Democracy in relationships with people; creativity Presenting not only the result but also the process, self-actualization is accompanied by the reflection of the subject of their success in the path of development (Maslow, 1999; Rogers, 1994). It also seems to be important to realize the limitations that impede its translational selfmotion in terms of interaction with the real and virtual environment.

The information society requires from a person the ability to independently acquire knowledge, master the information technologies. Search, comprehension, deepening and application of such technologies are becoming an organic need for everyone. Creating a tense and useful informational environment for adults and youth is a key task for the development of a society of information type (Petrik, 2007: 45-46).

The impact of the virtual environment can be both positive and negative. On the one hand, excessively being in the virtual reality, young people may lose interest in independent thinking, reading, manual labor, becoming passive consumers of information, and on the other hand, some of them use the Internet as a library and source of information. The facilitated method of obtaining additional knowledge through the network promotes the development of cognitive activity of man (Abdrakhmanova, 2017: 14-17; Khilko, 2015: 56-60). Thus, virtual reality is increasingly becoming an essential component of the organization of people's lives, and its influence on the development of self-actualization of a modern man requires a special study.

\section{Methodology}

An empirical study was conducted with the participation of 223 young people under study: graduate students, students from different universities of Kyiv, youths without higher education, young working people. Among them: 
117 males, 106 females; 79 graduate students, 120 students, 24 have secondary education; 112 working ones and 111 - not working.

The following research methods were used in the work: testing (Kimberly Young Test, CAT Test and Situational Self-actualization Test), questionnaires, observations; statistical methods for carrying out qualitative and quantitative analysis of the research results (Student's criterion and Pearson criterion).

The questionnaire, which was created for the research purposes, was intended to differentiate the sample into groups by type of Internet usage. Table 1 shows the porcelain distribution of the participants who participated in our study on the prevalence of their use of the virtual network.

Table 1

The distribution of respondents according to the criterion of the advantages of using a virtual network (\%)

\begin{tabular}{|l|c|c|c|c|c|}
\hline & High schools+job & High schools & School & Job & Nothing \\
\hline Online game & 4,2 & 37,5 & 12,5 & 20,8 & 25,0 \\
\hline Communication & 6,7 & 70,0 & 10,0 & 10,0 & 3,3 \\
\hline Information search & 14,8 & 62,9 & 3,7 & 18,5 & 0,0 \\
\hline
\end{tabular}

In our previous publications (Golovanova, 2016: 12-18; Golovanova, 2017: 32-35) on the materials of the survey 223 Internet users by $\mathrm{K}$. Yang's method and the SAT test, the following was established:

1. The connection between the passion of virtual space and self-actualization of the personality of adolescence was established at 99.9\% of significance level. (temp $=9.2$, tcr $=$ 3.7 for $\mathrm{p} \leq 0.001$ )

2. The impact of various options for using the virtual space for self-actualization was established in the following context: the level of self-actualization of youths who favor online games and have an Internet degree of dependence above average, differ from the level of self-actualization of youth, who prefer online communication and have the degree of Internet dependency above average in the high level of statistical significance $(99.5 \%$; temp = 3.19 , $t c r=2.778$ for $\mathrm{p}>0.01$ ), and from youths who prefer information searches and have an Internet degree of dependence above the average, at an absolute level of statistical significance $(99.9 \%$; temp $=5.55$; tcr $=3.7$ for $p>0.001)$. Levels of self-actualization of groups of online communication and information search are not statistically different $($ temp $=1.13$, tcr $=2.059$ for $\mathrm{p} \leq 0.05)$.

3 . With the rise a time that a person spends in the virtual space, the level of self-actualization with a 95\% level of significance decreases. This is for Internet addicts who mainly use the virtual space for online games $(\mathrm{rpm}=0.447$, $\mathrm{rKr}=0.4$ for $\mathrm{p} \leq 0.05$ and $\mathrm{rKr}=0.52$ for $\mathrm{p} \leq 0.0$ ). For people who use virtual space for another purpose - an increase in time does not have a direct impact on self- actualization. (remp $=0.1$, $\mathrm{rcr}=0.25$ for $\mathrm{p} \leq 0.05$ )

4. It was also found that in $60 \%$ of human achievements, obtained during the intensive use of the virtual space, can increase the subjective evaluation of achieved self-actualization at a low level of its objective state.

5. In uncommon cases, respondents noted that virtual achievement increases their mood and a sense of comfort, despite the fact that in the real space there is an opposite process (problems at work, low marks in the studies, dissatisfaction with the chosen profession, etc.) (Rogers, 1994).

Based on the data obtained, we have developed a program of psychological support for the self-actualization of youths by developing its competence in using Internet resources. The program provides for work with respondents with the lowest indicators of self-actualization in the SAT method, selected at the stage of the study. Of these respondents, two groups of 50 people were formed, one of whom received psychological online support, and another had a status of control group.

Solving the problem of increasing selfactualization of the personality of younth with the use of resources of the virtual space provided for the development of a model of psychological support for such a process. The basis of the development of such a program laid the principles: taking into account the theoretical foundations of the phenomenon self-actualization of the individual; orientation on the psychological 
peculiarities of younth; dynamism, curiosity and semantic value of classes; variety of forms of work. The program was created as a combination of the three main forms of support: information, online training and individual consultation. Such a design is due to the fact that for the first time in the history of civilization people have access to a huge array of information and various services.

The choice of an increasing number of people for the benefit of the Internet is prevalent in that they experience, as a rule, positive effects associated with its use. At the same time, some people are not able to critically assess the consequences of excessive use of information technology for their lives, while the other already consciously avoids the negative impact that becomes possible in the case of uncontrolled use of Internet resources (Khilko, 2015: 56-60).

The main idea behind the developed support program is to focus the young person's attention on her own problems related to the unproductive and excessive use of the virtual space, to provide them with systemic information about how to use this space safely and for the benefit of developing him own personality.

On the other hand, today people are choosing the Internet massively in search of therapeutic interventions and group communication. And mental health professionals are looking for new ways to provide psychological help through the Internet. Internet resources for psychological support offer their users not only social support and practical information, inspiration, but also group work on the exchange of experience, positive role models and professional support. The indicated psychological assistance tools for participants in such virtual groups work online no less productively than in real face-to-face groups.

That is why the basic vector of organization psycho-consulting part of the program of psychological support was chosen its implementation in the Internet space. This format provided the participants with the opportunity of anonymous collaboration with a specialist and people of the same age to modify (vary) behavioral scenarios and develop personal resources.

Online communication with the participants of the program was carried out in several stages in the forms of individual counseling and group webinar.

The first part of the implementation of the program of psychological support for the development of self-actualization of youth was the work to intensify their self-knowledge. It consisted of two stages: (motivation and awareness). At the stage of motivation, the motivation of Internet addicted people to participate in the program was created to enhance the desire to change oneself. At the next stage - awareness, activation of selfknowledge was carried out by familiarizing young people with the theoretical foundations of the process of self-actualization, which provided participants with awareness of their individual characteristics, deepened their perceptions of themselves and their actual state, made it possible to see and feel more authentic, unique, friendly, open, strong and creative.

An important task of this stage was also the need to focus the attention of Internet addicts on the problem situation in which they are located, to provide complete information about the negative aspects of Internet dependence and low level of self-actualization of the person, to reflect on the indicators of self-actualization, obtained during the work with the test SAT

Individual work with respondents was organized according to the following scheme: scheduled online meetings once a month with each participant and unscheduled meetings, at the request of the participant (as a rule, one meeting during the duration of the support program).

Work on scheduled online consultations was conducted in the following scenario: 1) Recognition of the problem. The stage is intended for educational work, examples and overcoming the opposite (denial of the fact) by a person. 2) Investigation of the problem. At this stage, it turns out how the influence (dependence) manifests itself, when it began, as it progressed. 3) Monitoring. Investigation of the family and social situation of a person. Inventory of a person's condition (physical, psychological).

4) Encouragement. Work with the capabilities and resources of the person (with himself-esteem and acceptance of herself). 5) Plan. Coordinating a clear plan of action with the person to overcome the negative effects (reducing the time online, shifting emphasis, the cultivation of hobbies in the real world, etc.). 6) Providing new meanings to the life situation (analysis of skills and interests of the client and identifying new areas of interest to him) (Peseschkian, 1987).

The second part of the training program, aimed at increasing the productive use of virtual 
space, was implemented in the form of a webinar with all participants in the training group and was designed for four meetings of 3 hours duration.

On the webinar, work with a group of participants was conducted using the tools of positive psychotherapy and envisaged focusing on the key areas for this methodology for analysis: body and health, activities and communication, planning and the future (Peseschkian, 1987).

Receiving feedback from participants on changes in self-awareness took place in the form of a written reflection of their own experiences at the end of each of the four training days.

Six months after the completion of the program of psychological support for Internet addicts in order to increase their self-actualization, the participants of the study passed a selfactualization test again. This second test section was performed using SAT in experimental and control groups.

The results of testing the maintenance program should be considered on the basis of a combination of subjective and objective indicators of its effectiveness. Let's start with the fact that in the process of online activities of the psychological support group with its participants there were significant changes that the young men noted in their self-reports during the individualadvisory work. Briefly, their generalized meaning, obtained using the procedure of content analysis of the participants' feedback texts, is as follows:

1. The communicative competences of the participants of the program acquire the optimal expression that manifests itself in the emergence of constructive (dialogic) models of communication and interpersonal skills;

2. The level of social and psychological competence is increased: developing orientation skills in diverse social situations, the ability to adequately assess the communicative situation, forecast trends in its development;

3. There is a development of internal and external freedom, spontaneity of behavioral scenarios of participants;

4. Their self-esteem, self-assurance, responsibility for decisions made;
5. Improvements in empathy, emotional sensitivity; developing imagination, creativity of youth;

6. Their search activity is increased, orientation towards an active life position is actualized;

7. The ability to personal reflection of participants of the program, ability to analyze the history of their life and past experience and to comprehend prospects of life plans is improved.

These changes, identified on the basis of content analysis of feedback texts, self-reports and individual work of participants, also reinforce the data comparing the results of the self-actualization test on ascertaining section 1 and 2 obtained for the experimental and control groups. The statistical data given in Table 2 (see next page below) demonstrate significant positive changes in the indicators of various characteristics of selfactualization of the participants of the formative research program.

The hypothesis about the difference between the group's indices before and after testing the program is taken at 0.01 level of significance (tcr $=2.682$ for $\mathrm{p} \leq 0.01$ ). Based on these calculations, we can speak of statistically significant differences at a significance level of $99.9 \%$ for indicators: time orientation, value orientations, and sensitivity to oneself, spontaneity, self-esteem, self-perception, perceptions of human nature and nature, synergy, acceptance of aggression, cognitive needs, and creativity. Detected differences between the two groups are significant more than 0.05 levels (tcr $=$ 2.011 for $\mathrm{p} \leq 0.05$ ) for indicators: contact, support, flexibility of behavior. Therefore, based on these calculations, we can talk about statistically significant differences in $95 \%$ of cases for these three indicators. The most significant changes were obtained by: time orientation, selfperception, ideas about human nature, synergy, spontaneity and cognitive needs.

The statistics delivered in Table 3 show changes in the second pass of the SAT test for the control group.

For the control group, no statistically significant difference was found between the results of the first and second passage of the test. 
Results of self-actualization test (SAT) for respondents of the experimental group before and after the program of psychological support

\begin{tabular}{|c|c|c|c|c|}
\hline $\begin{array}{c}\text { Average values: } \\
\text { SAT scales }\end{array}$ & First cut & Second cut & Change in $\%$ & temp \\
\hline Time orientation scale & 38 & 45 & 18 & 3,7 \\
\hline Support scale & 44 & 49 & 18 & 2,6 \\
\hline Value scale & 45 & 51 & 13 & 2,8 \\
\hline Behavior Flexibility scale & 47 & 49 & 4 & 2,2 \\
\hline Sensitivity scale & 46 & 53 & 15 & 2,9 \\
\hline Scale of spontaneity & 39 & 46 & 18 & 2,9 \\
\hline Self-esteem scale & 44 & 50 & 14 & 2,7 \\
\hline Self-acceptance scale & 45 & 54 & 20 & 4,2 \\
\hline Scale of ideas about human nature & 40 & 48 & 20 & 4,5 \\
\hline Synergy Scale & 42 & 50 & 19 & 3,2 \\
\hline Scale making aggression & 43 & 49 & 14 & 2,8 \\
\hline Scale of contact & 48 & 51 & 6 & 2,4 \\
\hline Scale of cognitive needs & 45 & 53 & 18 & 4,1 \\
\hline Scale of creativity & 46 & 52 & 13 & 2,7 \\
\hline
\end{tabular}

\section{Discussion}

In the order of the discussion, we note that in the study Khilko O.V.

Internet addiction is seen as an exclusively negative factor.

Table 3

Results of the self-actualization test (SAT) for the control group before and after the program of psychological support

\begin{tabular}{|c|c|c|c|c|}
\hline $\begin{array}{l}\text { Average values: } \\
\text { SAT scales }\end{array}$ & First cut & Second cut & Change in $\%$ & temp \\
\hline Time orientation scale & 37 & 38 & 3 & 0,5 \\
\hline Support scale & 42 & 42 & 0 & 0 \\
\hline Value scale & 45 & 46 & 2 & 0,4 \\
\hline Behavior Flexibility scale & 45 & 46 & 2 & 0,5 \\
\hline Sensitivity scale & 45 & 45 & 0 & 0,1 \\
\hline Scale of spontaneity & 38 & 38 & 0 & 0 \\
\hline Self-esteem scale & 45 & 47 & 4 & 0,5 \\
\hline Self-acceptance scale & 46 & 48 & 4 & 0,4 \\
\hline Scale of ideas about human nature & 41 & 42 & 2 & 0,3 \\
\hline Synergy Scale & 42 & 42 & 0 & 0 \\
\hline Scale making aggression & 43 & 45 & 5 & 0,6 \\
\hline Scale of contact & 49 & 49 & 0 & 0,1 \\
\hline Scale of cognitive needs & 44 & 44 & 0 & 0 \\
\hline Scale of creativity & 45 & 46 & 2 & 0,2 \\
\hline
\end{tabular}

Methods of combating this dependence are considered in terms of opposing the virtual world to the real. It is noted that the passion of the virtual space of a person can occur on the basis of the lack of real social contacts with peers and the lack of real achievements, pushing people to realize themselves in the victories of online games. One of the points of work with dependence is offered a competition of works on the topic "What can I lose from the computer?"

Contrary to this approach, in our support program, emphasis is placed not on counteraction to the Internet activity of the personality of adolescence, but on the shifting of emphasis for boys toward productive options for its use. In other words, instead of criticism and abrupt 
abandonment of its use, the option of increasing competence in the use of information technology and the use of the Internet, not as a substitute for the real world but as a means of achieving personal and socially meaningful goals in this world, is considered.

\section{Conclusion}

In the course of an empirical study carried out, the authors prove the statistically significant relationship that exists between the excessive capture of the personality of the youth by virtual space and its self-actualization.

The analysis of the influence of various variants of use by young men of the virtual space (games, communication, information seeking) revealed a significant difference in the priority of the gaming activity of youth as a factor in the formation of Internet dependency and low selfactualization of the individual (the latter is understood by the authors as an integral individual indicator of personal growth of a person).

As the experiment with a group of Internet dependent addicts of younth age showed, the program of psychological support of youth of the youth by the development of their competence in using Internet resources is developed to reduce the Internet vulnerability.

In the future, it would be advisable to extend the time frame for research to identify the factors and conditions for maintaining the effect of changes over a long period of time without the influence of the researcher. And also to supplement the experiment with indicators aimed at revealing real changes in the educational, professional and creative life.

Conflict of interest. We state that there is no conflict of scientific interests.

\section{References}

Abdrakhmanova E. V. (2017) Sovremennye predstavleniia 0 faktorakh, sposobstvuiushchikh formirovaniiu internetzavisimosti [Contemporary ideas about the factors contributing to the formation of an online dependence]. Aktualnye voprosy sovremennoi psikhologii: materialy IV Mezhdunar. nauch. konf. [Topical issues of modern psychology: Materials of IV International Scientific conf.]. Krasnodar: Novatsiia, 14-17. URL: http://moluch.ru/conf/psy/archive/237/1180 4/ [in Russian]
Golovanova T. M. (2016). Psykholohichni osoblyvosti aktualizatsii sebe osoby yunoho viku u virtualnomu prostori [Psychological peculiarities of self-actualization of a person of juvenile age in a virtual space] / $\mathrm{T}$. Golovanova. Naukovyi visnyk Khersonskoho derzhavnoho universytetu [Scientific Bulletin of the Kherson State University]. Kherson, 2016. - Ser.: Psykholohichni nauky [Psychological sciences], 3, 12-18. [in Ukrainian]

Golovanova T. M. (2017). Zviazok mizh entuziazmom virtualnoho prostoru i samorealizatsiieiu osoby molodi [The connection between the enthusiasm of virtual space and self-realization of the personality of the young man] / $\mathrm{T}$. Golovanova. Visnyk Kyivskoho natsionalnoho universytetu imeni Tarasa Shevchenka [Bulletin of Taras Shevchenko National University of Kyiv], Ser.: Psykholohiia [Psychology],Vol. 1 (6)-2 (7), 32-35. [in Ukrainian]

Vashchenko I.V., Vlasova O.I., Danyliuk I.V. et al. (2016). Dosvid mizhdystsyplinarnoho doslidzhennia rozvytku tsilisnoi osobystosti $\mathrm{v}$ konteksti sotsialnykh zmin [Experience of interdiscipline -national study of the development of a coherent personality in the context of social change]. Psykholohiia $i$ osobystist [Psychology and personality], № 2 (10) part 1, 116-127. [in Ukrainian]

Maslow A.G. (1999). Samoaktualizirovannye Liudi: Issledovanie psikhologicheskogo zdorovia (Motivatsiia i lichnost) [Self actualized People: The study of psychological health. (Motivation and personality)] / AG Maslow; per. AM Tatlybaeva, Spb: OCR: Ichthyk. [in Russian]

Rogers K. A Look at Psychotherapy. Formation of a person. / K. Rogers - M.: Progress, 1994. $478 \mathrm{pp}$.

Petrik V. (2007). Nebezpeky informatsiinoho prostoru dlia osobystosti [Dangers of the Personality in the Information Space] / V. Petryk, Ya. Zharkov, M. Dzyuba. Legal Magazine, 2, 45-46. [in Ukrainian]

Khilko O. V. (2015). Prakticheskii podkhod k profilaktike kompiuternoi zavisimosti u podrostkov [Practical approach to the prevention of computer dependence in adolescents]. Nauchno-metodicheskii 
elektronnyi zhurnal «Kontsept» [Scientificmethodical electronic journal "Concept"], 3, 56-60. Retrieved from http: //e-
koncept.ru/2015/85012.htm. [in Russian] Young K. S. (2000). Diagnosis - Internet addiction
/ K.S. Young / World of Internet. - M., - No. 2. P. 36 - 43.

Peseschkian N. (1987) Positive Psychotherapy Theory and Practice of a New Method / Nossrat Peseschkian. Publisher: SpringerVerlag, Berlin. ISBN 978-0-387-15794-8 